internet: surfing, searching, and browsing in the search Engine like Google. Today, in the 21 st century or industrial revolution 4.0 and Web 2.0, technology is an inseparable part from a human life. It absolutely alters the manner the society looks and the people communicate in society (Sutton, 2013). Many human activities are mostly assisted by sophisticated technology like networks helping people buy, transfer, deliver, and communicate among others in virtual ways fast and easily. People just use one touch on the smartphone to respond what people want in transactional processes in a daily life. Furthermore, the term of social media has been a new habit in getting new information and social interaction in the form of virtual space. For expressing and delivering an idea, a message, thinking, and also opinion, people use social media like Facebook, Instagram, Twitter, etc. People are no longer in real meeting in the same place for chatting and discussing. People just sit and watch the screen of smartphone.

Again, technology has contributed in handling education (Ahmadi, 2018). Some preservice teachers utilize it for communication, entertainment, and education (Boholano, 2017). In the educational field, technology is very necessary in helping teachers deliver and transfer knowledge to the students and exactly for achieving learning objectives. It can simplify teaching and learning processes to be more effective and efficient. The rise of new manner in learning transmission and tendency in workplace require independent learning ( $\mathrm{Ra}$ et al., 2019). It also can build an environment of social learning (Abdelraheem \& Ahmed, 2018). Moreover, technology has assisted for language teaching and learning continuously begun with traditional means as chalk and blackboard to the modern ways such as film, audio, and video which are available to many teachers (LarsenFreeman \& Anderson, 2011). It has some basic roles in language education: as resources, system of delivery, and productivity (Ghanizadeh et al., 2015). Nowadays, of course, the emergence of digital tools has penetrated to teaching media as well like internet connecting all people in the world. The internet contribution toward language teaching is expeditious (Mofareh, 2019). As technology develops, MOOCs, social network and internet store are extremely used in learning (R. Huang et al., 2019). The term of Mobile Assisted Language Learning (MALL) apps: WhatsApp, Instagram, Facebook, YouTube, etc can be

\section{Adhan Kholis}


used in learning English (S. S. Ahmed, 2019). It can strengthen the different skills like vocabulary mastery (Hassan Taj et al., 2017) and attitude toward learning processes inside the classroom (Robles et al., 2019). Teachers can freely set and broaden communication outside of the classroom providing the everlasting learning (YeşiLel, 2016).

The challenges of social media in learning get deliberation inasmuch as there must be more problems especially during operating platforms (Singh, 2018). Students should use high technology like android, smartphone, PC, and iPhone for connecting in learning. In fact, students mostly have a low bandwidth so that when students want to reach teachers' instructions and materials, there are lots of difficulties to be on the teachers' room. Indeed, the security in accessing toward many issues on internet becomes concern both teachers and students. Students should prioritize social media for either learning or entertaining. Also, for new commers in the distance education, it is regarded as unfamiliar tools for teachers in practice for the reason that many teachers used to conduct teaching in face-toface environment or traditional ways rather than online one. Teachers used to interact to students without any space and distance giving feedback, correction, and evaluation related to students' mistakes directly. Consequently, the teacher should change the traditional paradigm to digital ways.

Indeed, teachers require more time and lots of works only for creating modules and teaching materials. Teachers think more to prepare and to identify the students' need and want to be engaged in the online class. Here, teachers are as a facilitator handling the processes of teaching. Distance learning insists teachers to do more tricks in designing language teaching meaningfully because of limited length in interacting to students. In this case, firstly, communication gets more notable. Teachers need to conduct the online class similar with the faceto-face class modifying various knowledge in order that students can understand materials comprehensively. In addition, teachers should lead an unfamiliar environment by guiding and orienting students to be practice in online. Secondly, teachers must have more background knowledge in handling distance learning. It means that teachers are familiar with virtual education alias knowing how to operate internet and networks. Here, to engage students active in new 
environments, teachers should develop types of awareness and skills. The more teachers can effectively dominate and handle the distance environment, the more students can easily adapt and understand the materials. Third, the teachers' readiness in preparing, planning, and developing the teaching design is fully dominant in achieving learning objectives.

Nowadays, the world encounters a shift in all sectors including education due to the corona virus (covid-19). It requires transformations and modification in the system of education like an emergency curriculum of covid-19 and teaching method. A number of policies have been established by Ministry of Education and Culture like Work from Home (WFH), distance learning (PJJ), school closure, and even cancellation of the national exam. It sustains policy makers, stakeholders, and teachers to adapt educational system such as making new curriculum and conducting remote teaching, however; this compulsion is being considered by teachers for many reasons and assumptions regarding with the effectiveness of teaching and learning processes itself. Some factors: sufficient methodology and pedagogy, readiness to use new technology, and teachers' competences should also be regarded (Memić-Fišić \& Bijedić, 2017). Practically, there must be some obstacles during conducting online learning. Firstly, the modality in connecting in the virtual ways is limited. Timing and costs may also be consideration for all parties: teachers, students, and even parents. Secondly, the interaction and communication in learning become not effective because teachers cannot immediately meet in face-to-face learning. It makes teachers difficult to motivate and to assess students' learning progress.

For those conditions, definitely, the emergence of many digital platforms in learning can be an alternative solution due to benefits gained from apps: simplifying teachers to explain materials, giving instructions, and communicating with students. Teachers need to choose an appropriate app in accordance with the students' needs and require to consider many aspects related to distance learning such as the students' readiness in joining virtual meeting, delivered materials, tasks and assignments, learning facilities, and evaluation. Some declare that using video conference (real time) can help teachers reach students' presences in talking, interacting, and communicating. Both teachers and students can meet 
together in the same time and places, however; the basic problem in meeting with video conference is that there is no recourse when technology collapses immediately in the middle of learning (Roux et al., 2014). Some obstacles dealing with the technology uses: a signal, internet accesses, and a quote are often encountered by the students. Again, the modality of using synchronous app is considered because it needs more extent and access. The lack of computer spec and internet access both in campus and private is low and poor (Mardiana, 2020).

Clearly, it is necessary for teachers in selecting an appropriate mode for reaching students in distance learning in order that learning becomes effective and efficient. The convenience of digital uses should be consideration in assisting teachers manage materials and set the students. The students' ease in reaching teaching resources and engaging in learning room also gets concern (R. A. Huang et al., 2020). Mainly, teachers should consider the students' needs and wants rather than just use the high technology. Teachers can examine asynchronous communication. Definitely, it is suitable for maximizing virtual environment during pandemic covid-19 because of low tech, save quote, easy use, and easy internet access. Many apps categorized to be asynchronous communication: WhatsApp, Telegram, Google Classroom, Blogs, Podcast, Gmail, etc. All have strength and weaknesses in performances. In the asynchronous mode, teachers and students do not present at the same time in the communications (Murphy et al., 2011). Today's uses of asynchronous apps are regularly used for online discussion. It can build the social community and experiences of education: presence of cognitive, social, and teaching (deNoyelles et al., 2014). Again, it allows students with shortly available materials including audio, video, handout, and slides (Perveen, 2016). It is suitable and applicable for improving the students' vocabulary mastery (Lotfi \& Pozveh, 2019); (Khodaparast \& Ghafournia, 2015). The mode of asynchronous learning has the roles for humanizing online course by reiterating the classroom impression of exchanging information and social construct (Shahabadi \& Uplane, 2015).

Against to the background, this study concentrates on describing and investigating the application of WhatsApp App in distance language learning during pandemic covid-19. Indeed, the students' perception toward using 
WhatsApp would be explored. The researcher chooses WhatsApp App as media for online learning for the reason that WhatsApp is mostly used in a daily life activity in worldwide including Indonesia. Also, it is an easy use and light application can be utilized for many works and purposes including for learning. The subject of the study is the students and lecturers of English Education of Nahdlatul Ulama University of Yogyakarta. WhatsApp has been the mostly asynchronous communication used for language teaching today which has several functions on sharing audio, video, documents, etc. It is highly popular communication services (Kumar \& Sharma, 2017). Most people in worldwide used it for many tasks and works (Shahid, 2018). It also serves many tools and features in diverse functions including the common uses for collaboration, group discussion, and even cooperative learning activities. The students assigned to particular group discussion can chat, discuss, and share immediately. For big classes, the teachers can divide into several groups in the different purposes. Moreover, students can mention questions both off topic or attention matters among others during the class (Ko \& Rossen, 2010). WhatsApp also generate desired learning and social benefits (Alenazi, 2017). Students who used it in learning process perceive to be easy, fun, and useful (Gasaymeh, 2017).

\section{METHOD}

The study was a qualitative research in the form of a case study design. It was organized to describe, explore and evaluate the utilization of WhatsApp App in distance language learning for the English Education Department Students of Nahdlatul Ulama University of Yogyakarta. For the subject of the study, the researcher chose the students of English Education Department and some English Education lecturers to be respondents. There were at least 40 students. In this design, the researcher used some data collection techniques like interview, questionnaire. observation, and documentation in obtaining data. Collecting data in this study was done by interviewing five English Education Lecturers and some students to get relevant data in relation to the use of WhatsApp App in language teaching during pandemic covid-19. Indeed, the students' perception, motivation, and satisfaction were investigated by giving questionnaire to the students in the form of essay questions related to the use of WhatsApp App. Because this study 
was conducted during pandemic covid-19, the researcher share questionnaire in the Google form. In analyzing data, the researcher reduced, displayed, and concluded the data.

\section{Data Collection Techniques}

Here, for collecting data, the researcher used interview, questionnaire, observation, and documentation. The primary data sources used were obtained from interview and questionnaire, whereas the observation and documentation became the secondary data for supporting the main data. The form of data of this study was the use of WhatsApp App in distance language learning and the students' perception, motivation, and satisfaction in using WhatsApp App during distance learning. The researcher interviewed five English Education Department Lecturers and some students to get data about the use of WhatsApp in distance learning and the perception of using it for teaching and learning processes. For obtaining the students' perception, motivation, and satisfaction about the use of WhatsApp, the researcher used questionnaire in the form of essay questions in relation to the students' responses toward the use of WhatsApp App during pandemic covid-19. There were at least 40 students of English Education Department to had questionnaire. Documentation was in the form of WhatsApp chats screenshot.

\section{Data Analysis}

After getting the data, the researcher analyzed the data. In this case, the researcher reduced, displayed, and concluded the data. The researcher ignored and reduced the irrelevant data by giving codes and notes. Then, to serve e detailed data, the researcher selected an appropriate data in relation to the effectiveness of WhatsApp in distance language learning. Indeed, for checking data validity, the researcher used triangulation to be as a comparison of data. It was used for increasing the credibility and trustworthiness of a study (Saldaña, 2011). Indeed, it was used for comparing both primary and secondary data that was data taken from interview, questionnaire, and documentation. Here, the researcher found the similarity of data between the data of interview and questionnaire.

\section{Adhan Kholis}




\section{FINDINGS AND DISCUSSIONS}

Based on the study having done by the researcher, there were some findings concerning to the effectiveness of using WhatsApp App in the distance language learning during pandemic covid-19. Firstly, it was about the use of WhatsApp App in the distance language learning. The findings were drawn from the results of interviewing of the English Lecturers and some students in the form of transcript of interview. For supporting data, the students' answers in the questionnaire would be served. The researcher took some for explanation. There were at least some questions with regard to the use of WhatsApp App as follow as:

Researcher: [What apps do you usually use in delivering materials to students in online learning during this pandemic? Give the reasons for utilizing the apps!]

Lecturer: [I often used WhatsApp App in teaching English because of many reasons: I simply sent lots of teaching resources and materials like pdf, word, excel, power point (ppt), video, voice, and pictures. The students also easily accessed and responded it fast. For discussion and presentation, they always chose WhatsApp App. They were very enjoyable and enthusiastic in joining the online class].

Researcher: [What advantages do you get of using WhatsApp apps during online learning?]

Lecturer: [Okay, I got lots of benefits of using WhatsApp App when I taught English in virtual meeting. Firstly, I enjoyed sharing teaching materials. I no longer thought the stuck of internet access, because WhatsApp was so light in use. The speedy of transferring and sending messages was so fast so that the students directly responded it and opened materials given].

Researcher: [What are the strengths of WhatsApp App compared to other application?] 
Lecturer: [WhatsApp was mostly application used by most people in the world including Indonesia. I thought most teachers in Indonesia had the same statement about it. WhatsApp had many features can be used by teachers in delivering materials like sharing many forms of resources: pdf, word, video, pictures, podcast, etc. Also, it can be used for discussion and presentation either orally or written. This app was so smart in assisting me manage the online class to be more active].

Researcher: [What are the students' responses toward using WhatsApp App in distance language learning? Are they ready and happy to use it? Give your opinion!]

Lecturer: [Most students agreed with the use of WhatsApp in online teaching. They were enthusiastic in following the teachers' instruction instead the students asked teachers to use it in the preliminary meeting. They said that WhatsApp was so simple and reachable app and easy in use. They were motivated in getting materials].

Researcher: [What best apps do you choose in distance language learning during this pandemic covid-19?]

The student I: [I realized that today we were in the issue of corona virus demanding us to not meet together in the same place. For learning, because we had limited quote and internet access, for me, definitely, I chose WhatsApp App for joining online class because it gave me more eases in accessing teachers' instructions and resources. It was a light technology. Everyone knew that it was an accessible app in doing activities and many works. I can easily open and share materials in the group chatting. I can chat with the teacher and my friends directly. Indeed, materials having shared by the teacher in group can be opened and repeated for drilling courses so that I enjoy using it. Every time and everywhere I was, I can successfully access and open the materials].

The student II: [exactly I chose WhatsApp for online teaching and learning. Today, we all were in pandemic covid-19. Because I had little money for using high technology like video conference: Zoom, Google

\section{Adhan Kholis}


meet, Team link, and YouTube. I preferred to use light application for joining online class because it saved my money and quote].

The student III: [I like to use WhatsApp in the group discussion. I can share my opinion to all fast. Also, I can reach all in meeting room. Features given were handy for doing anything related to learning including I can write and delete paragraph in the chat room whenever I wanted. I can make video call and voice notes (VN) for calling and discussing. Indeed, when I wanted to share pictures or emoticon, it must be good in use].

Researcher: [What do you get of using WhatsApp App in online learning?]

The students I: [Okay, thanks you Mr. Adhan for question. Firstly, I felt very happy and comfortable when you used it for English learning. I can reach all of what you instruct me like greeting, setting the classroom, suggestion, advises, sharing, and chatting. This was a smart app of instant messages (IM) for interacting and communicating fast].

The student II: [I was very enthusiastic in joining online classroom because there was no stuck in applying WhatsApp. I got more positive social interaction like face-to-face learning. I was also more discipline in entering online class. When the teacher greeted in first, I responded it fast like messages. Indeed, I was motivated in learning English. I can add more lots of vocabulary. I can check my grammatical uses].

The Student III: [In fact, I was very enjoyed in online learning using WhatsApp. I no longer thought the modality or the cost for paying more quote. For learning writing, this app can help me to correct and write paragraph even text. I can link this app with other social media like Instagram and Facebook to get more relation and communication. To get more learning sources, I can share the pdf and word forms. Really, this app can successfully help me find more links and improve my writing skills.

Researcher: [Are there any obstacles when using WhatsApp App for distance language learning?]

\section{Adhan Kholis}


The student I: [As long as I used WhatsApp in the online class, I just found little problems in group discussion such as I missed chatting at times. When using it for discussion, I must be focus in noticing the teacher's instruction. Once I ignored the chat room, sometimes, I should swipe to the upper chat to find and read it. For all, I thought it was easy app in learning]

The student II: [There is a just little stuck but not much, because WhatsApp App is so light app than others like Zoom, Google Classroom. I was enjoyed using it for online class. We have a little money for buying high technology. Consequently, I decided to use it for learning. All my friends agreed with operating it for all online course.

Secondly, the findings are gained from students' answers in filling the questionnaire. There were at least 40 students responding it in the form of essay. But, because the questions were made in the Google form, there were some students filling the form because of low internet access. The researcher took some Google Form screenshots of the students' responses which linked to the research questions.

\section{Chart 1. Students' application preferences in the distance language learning}

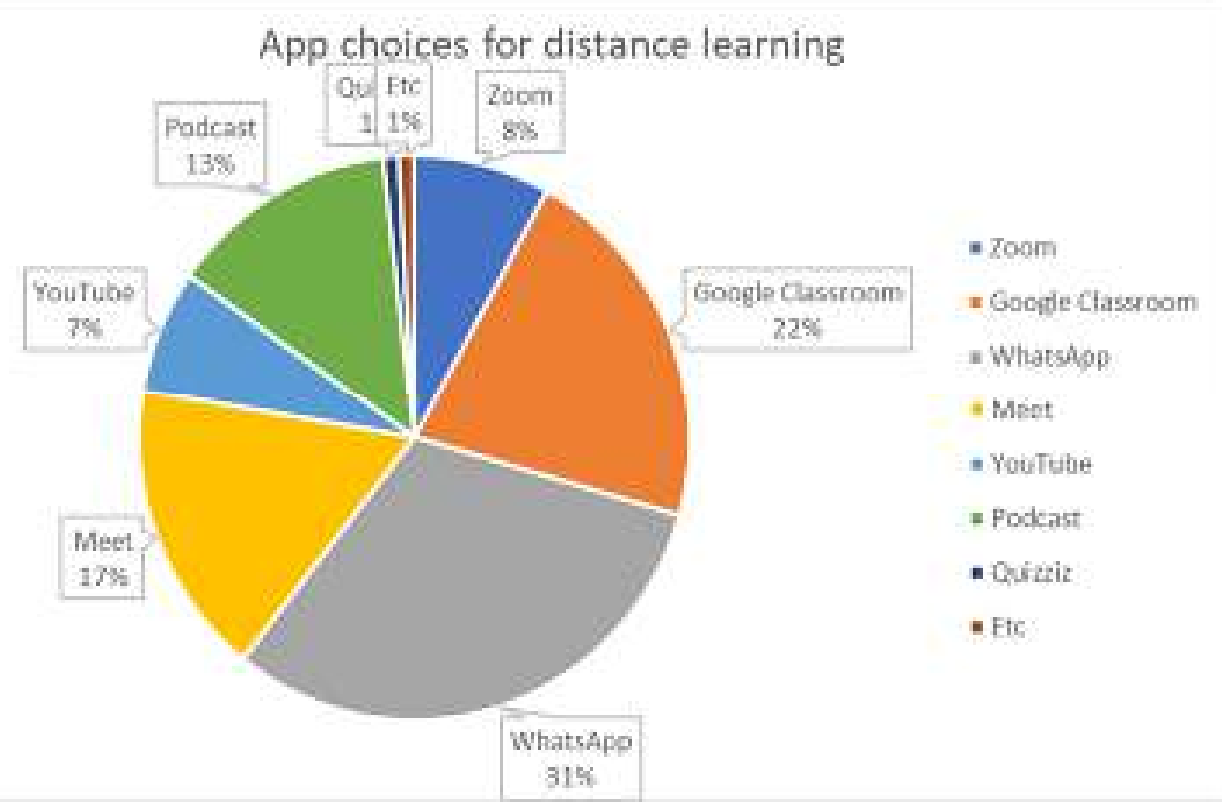




\section{Chart 2. The students' achievement in the distance language learning}

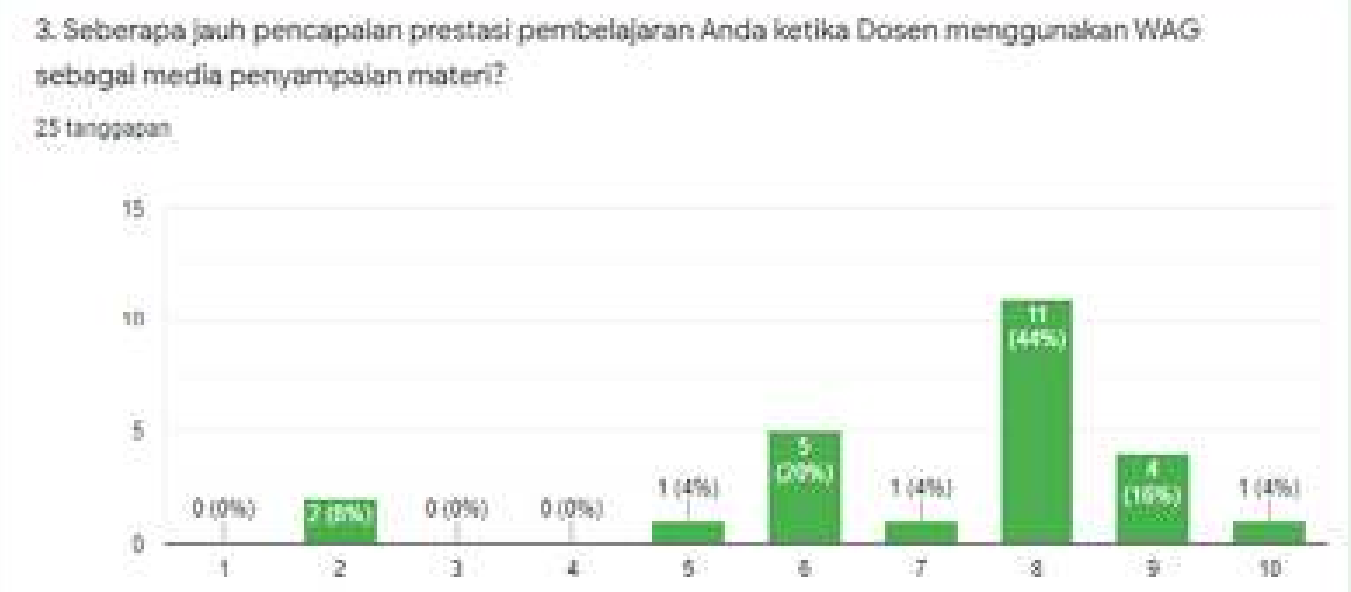

Table 3. Students' perception toward the use of WhatsApp

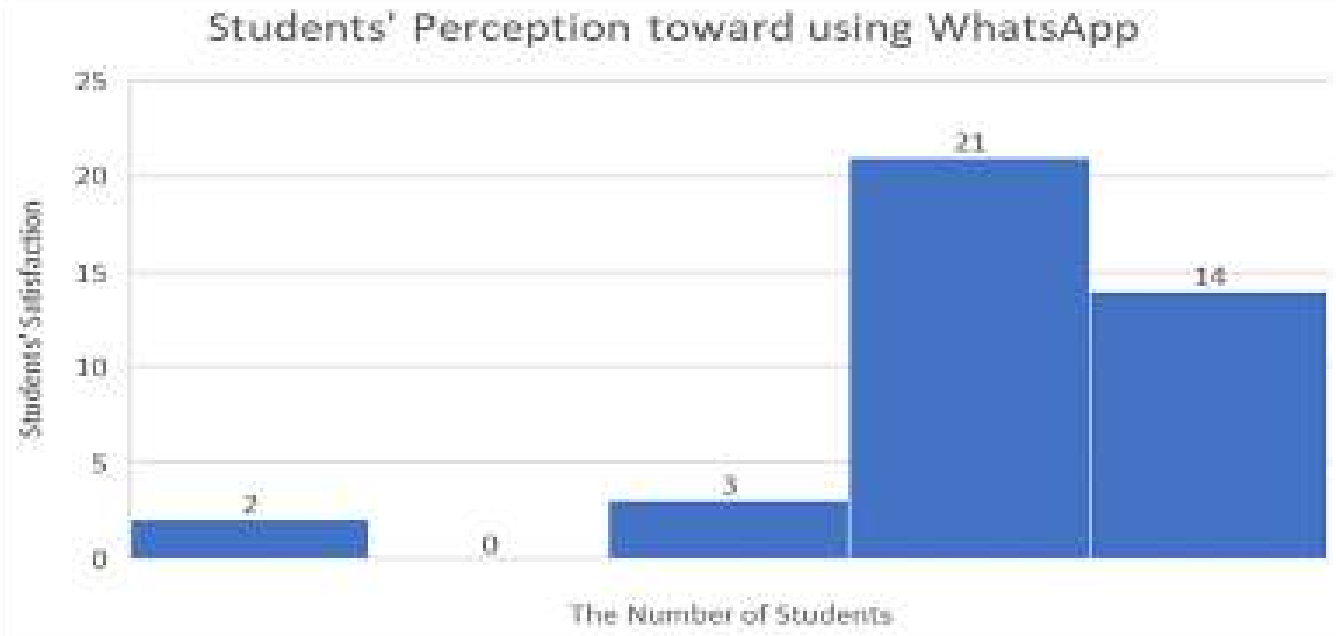

Based on the research findings elaborated in the previous section, the next part was the discussion regarding to the effectiveness of using WhatsApp App in the distance language learning during pandemic covid-19. There must be three issues would be discussed here: (1) the use of WhatsApp App in distance language learning (2) the students' perception, motivation, and satisfaction in using WhatsApp App in the distance language learning, and (3) the efficacy of 
using WhatsApp App in online learning of language. Based on the findings, the use of WhatsApp in the distance language learning during pandemic covid-19 was so effective and efficient. Based on some results of interview transcript addressed both the lecturers and the students, it can be resumed that all parties agreed with the use of WhatsApp app in online learning. Each resembled in the responses toward WhatsApp. Mostly, the answers were that WhatsApp app was so relevant for studying English language by distance for the reason that it was simple, light, and cheap in cost. For virtual communication, it was also clear and suitable for the students' condition which had the little cost for working on internet. This was equal to the (Linda \& Ri'aeni, 2018) and (Fattah, 2015) study stating that WhatsApp was effective for developing students' writing skills and creativity. Indeed, it contributed in serving more facilities and simplicities in language teaching. Both teacher and students were more focus in the substance rather than maintaining the app. It was so cheap app not consuming more signal and quote in practice so that students no longer thought about the cost. The teacher can share anything fast as well as students do. The teacher can interact and communicate with students in the chat room clearly without any stuck. For other benefits of WhatsApp, it was smart asynchronous communication. It was beneficial app in helping teachers teach in virtual classes. The students must not enter and present in the real time, but the students can open and access materials in another time whenever and wherever the students want. Lots of diverse material given can be read and looked again in the smartphone. In addition, because of the students' limited modality in using high technology, students preferred to use a light application like WhatsApp. Evidently, majority of the students used it for following learning.

In relation to the second discussion about students' perception toward WhatsApp App in distance language learning, inevitably, this app can be effective tools in enhancing language skills and students' rapport and motivation. The evidences shown in the chart highlight that the students' perceptions against WhatsApp App in online language learning were so significant. There were three graphs explained in differences. Firstly, it focused on the students' app choices toward online learning. Based on the chart, it indicated that the WhatsApp app

\section{Adhan Kholis}


became the main students' preference, about $31 \%$ of students chose WhatsApp app for online learning tools in pandemic covid-19. It suited with the students' interview transcript stated that WhatsApp was good app in that it was so cheap and a friendly tool. The second chart was addressed to the students' success or achievement after using WhatsApp. About $88 \%$, the students got advanced in learning, whereas about $12 \%$ of residue, the students obtained low scores in learning. This indicated that WhatsApp App can be effective tools for remote teaching in post pandemic covid-19. It corresponded with the interview declaring that the students can successfully follow all teacher's instruction and join the class easily. The students can address lots questions and answer the teacher's statement in the dialogues. The last chart told the students' satisfaction during using WhatsApp in learning. In relation to the chart, about 35 of students or $90 \%$ in responses, the students felt happy and pleased in learning. This represented that WhatsApp app gave more contribution in distance language learning. It provided significant benefits for the students in engaging the learning. For language teaching, the students can reach all skills including listening, speaking, reading, and writing interchangeably. The line of diagram pointed the students were satisfied and success when the students use WhatsApp App in online learning. Here, for instance, during question and answer sessions, the students can successfully be able to chat and interact among others easily. All students can join in learning engagement sharing each other to make meaningful communication. Mostly, the students chose WhatsApp application for doing online learning than others for the reason that WhatsApp was different from other apps. This was app which can synchronize with other apps like Facebook, Instagram, and Messenger. Both the teacher and students can send and share files on those app. It was suit with the (Susanti \& Tarmuji, 2016) research using WhatsApp for teaching writing to senior high school students. With regard to the students' motivation and responses toward WhatsApp, the study conducted by (Dewi, 2019) in Technology University of Yogyakarta said that the use of WhatsApp during learning processes can bring in more positive students' responses. The spirit of study on online learning was so high in that they preferred to engage in simple and cheap mode. Mostly, when the teacher utilized the high bandwidth like Zoom, the students

\section{Adhan Kholis}


cannot present so that the materials given to them were cancelled. It also corresponded with the (Mufanti \& Susilo, 2016) research which declares that WhatsApp can lead the students' attitude toward language learning such as confidence, independency, and enthusiasm. In this case, there were two kinds of conversation namely both dependent and independent talks. For the independent chats, the students freely discussed topics on chat room without any teacher's complicity. The students can talk each other in interpersonal interaction. The teacher just gave advices and correction and facilitated the students in order to make meaningful communication. Also, the teacher motivated the students to make good sentences in writing and observed them whether the students presented or not in the group discussion. On the contrary, in the dependent talks, the teacher leaded and guided the students to engage in the dialogues on WhatsApp. The discussion was formal like lecturing in off class. The teacher greeted the students, explained the learning objectives, and handled teaching and learning processes, while the students noticed and do exercises based on the teacher's instruction. Here, the students were actively guided to write the correct writing by regarding grammatical structures, word order, and diction. Indeed, group discussion on WhatsApp can incur the students to be engagement in language learning (Embi, 2016). Moreover, when the students came to join the group discussion, the intention and sense in noticing the teacher's instruction were highly so advanced. In the group discussion, the students were more active in asking questions toward the teacher's statements. The students can maintain and read lots of chats in groups in other time whenever and wherever the students were.

For the effectiveness of WhatsApp App was shown toward the successful uses and beneficial features contributing in the language learning. WhatsApp App services can support language learning as (Ma'ruf et al., 2019) proposed that it can help students in creating written text. Also, during chatting in groups, the students obtained lots of input of knowledge, vocabulary, and grammar. In this case, the students easily wrote words, phrases, clauses, sentences, even paragraphs in the chat room in relation to the topics discussed. For instance, when the teacher talked about the repots texts, then asked the students to inform the issues or news related to covid-19 in the form of statements or opinion, immediately, the students 
can successfully write based on their own judgement. Also, here, the grammar structures were checked and corrected by the teacher in order that the students directly knew what the errors and mistakes having made. For the assessment, the teacher simply gave some exercises and exam in the chat room in many forms: pdf and word. Again, for teaching speaking, the feature of voice notes (VN) can be used to engage and to help the students improve the speaking ability. The students can use voice note mode to speak with others. The student should maintain the formal utterance by considering the rules and norms in speaking. The roles of the teacher were just facilitator correcting the students' mistakes in sounding English words. The teacher can directly ask the students to revise and to improve the pronunciation. This was promoted by the (Nurazizah et al., 2019) result study claiming that voice notes in WhatsApp was appealing for speaking learning activity and accessible in use. In this case, the teacher can utilize the features of voice note (VN) for the purposes of explaining, asking, and answering orally. It was very simply. Both the teacher and students can press protractedly to record the voice and then share each other automatically. This, the students got time to increase the skills of speaking. The teacher can know the miss in pronunciation and correct it directly. In regard with the reading activities, the students can read lots of many diverse resources in the forms of e-book and pdf. For example, the students can link WhatsApp to other media like pdf in searching lots of English literature. Then, the students downloaded and read it in the smartphone. The students also can find and read out many article journals. This was supported by (S. T. S. Ahmed, 2019) study stated that WhatsApp App was a mobile digital application which can increase the students' motivation in enhancing the reading and writing skills and (Manan, 2017) also claimed that it can promote second language learning communicatively in both reading and writing. In teaching reading, for instance, here, the students read lots of pdf or word forms given on the dialogues. Indirectly, the students obtained more literature inputs and knowledge.

\section{CONCLUSIONS AND SUGGESTIONS}

The conclusion in this study is derived from findings and discussion delivered in the previous section aiming at answering the research questions. 
Firstly, the use of WhatsApp App in the distance language learning during pandemic covid-19 represented that asynchronous communication like WhatsApp App should be considered to be most effective media for teachers in delivering teaching materials due to lots of benefits in practice: (1) WhatsApp App is a low technology affording more facilities and simplicity in distance language learning (2) It is one of many apps used by most people in worldwide assisting for interacting and communicating in a fast response (3) Moreover, it was an easy use app than others for the reason that it was cheap, light, and save quote. Again, it must be comprehensive features can be discovered. Secondly, Students utilizing WhatsApp App in distance language learning get more advantages: (1) students can successfully access the teacher's instructions and materials in many diverse resources and forms easily and fast (2) students can save the more quote (3) students get more motivation and satisfaction including students feel enthusiastic, motivated, happy, welcome, discipline, and spirit. Finally, for this situation like pandemic, the more teachers creatively choose an appropriate media in remote teaching, the more teaching and learning become effective and efficient. Furthermore, the teacher should principally know the students' need and want rather than using high technology. The teachers should notice the students' modality in using technology.

\section{REFERENCES}

Abdelraheem, A. Y., \& Ahmed, A. M. (2018). The impact of using mobile social network applications on students' social-life. International Journal of Instruction, 11(2), 1-14. https://doi.org/10.12973/iji.2018.1121a

Ahmadi, M. R. (2018). The Use of Technology in English Language Learning: A Literature Review. International Journal of Research in English Education, 3(2), 115-125. https://doi.org/10.29252/ijree.3.2.115

Ahmed, S. S. (2019). WhatsApp and Learn English: A Study of the Effectiveness of WhatsApp in Developing Reading and Writing Skills in English. ELS Journal on Interdisciplinary Studies in Humanities, 2(2), 148. https://doi.org/10.34050/els-jish.v2i2.6419

Ahmed, S. T. S. (2019). Chat and Learn: Effectiveness of Using WhatsApp as a Pedagogical Tool to Enhance EFL Learners Reading and Writing Skills. International Journal of English Language and Literature Studies, 8(2), 61-68. https://doi.org/10.18488/journal.23.2019.82.61.68

Alenazi, A. A. (2017). WhatsApp Messenger as a Learning Tool: An Investigation of Pre-service Teachers' Learning without Instructor

Adhan Kholis

LET: Linguistics, Literature and Language Teaching Journal Vol. 10 No. 22020 
Presence. Journal of Education and Training Studies, 6(1), 1. https://doi.org/10.11114/jets.v6i1.2684

Boholano, H. (2017). Smart social networking: 21st Century teaching and learning skills. Research in Pedagogy, 7(2), 21-29. https://doi.org/10.17810/2015.45

deNoyelles, A., Zydney, J. M., \& Chen, B. (2014). Strategies for Creating a Community of Inquiry through Online Asynchronous Discussions. MERLOT Journal of Online Learning and Teaching, 10(1), 13.

Dewi, S. R. (2019). Utilizing Whatsapp Application for Teaching Integrated English (A Case Study at University of Technology Yogyakarta). REFLEKSI EDUKATIKA, 9(2), 8.

Embi, M. A. (2016). Students' Perception on The Use of Whatsapp As A Learning Tool in Esl Classroom. 4, 9.

Fattah, S. (2015). The Effectiveness of Using WhatsApp Messenger as One of Mobile Learning Techniques to Develop Students' Writing Skills. Journal of Education and Practice, 6(32), 13.

Gasaymeh, A.-M. M. (2017). University Students' use of Whatsapp and their Perceptions Regarding its Possible Integration into their Education. 17(1), 11.

Ghanizadeh, A., Razavi, A., \& Jahedizadeh, S. (2015). Technology-Enhanced Language Learning (TELL): A Review of Resourses and Upshots. International Letters of Chemistry, Physics and Astronomy, 54, 73-87. https://doi.org/10.18052/www.scipress.com/ILCPA.54.73

Hassan Taj, I., Ali, F., Aslam Sipra, M., \& Ahmad, W. (2017). Effect of Technology Enhanced Language Learning on Vocabulary Acquisition of EFL Learners. International Journal of Applied Linguistics and English Literature, 6(3), 262. https://doi.org/10.7575/aiac.ijalel.v.6n.3p.262

Huang, R. A., Liu, D. J., Tlili, A., Yang, J. F., \& Wang, H. H. (2020). Handbook on Facilitating Flexible Learning during Educational Disruption: The Chinese Experience in Maintaining Undistrupted Learning in Covid-19 Outbreak (p. 54). Smart Learning Institute of Beijing Normal University.

Huang, R., Spector, J. M., \& Yang, J. (2019). Educational Technology: A Primer for the 21st Century. Springer Singapore. https://doi.org/10.1007/978-98113-6643-7

Khodaparast, F., \& Ghafournia, N. (2015). The Effect of Asynchronous/Synchronous Approaches on English Vocabulary Achievement: A Study of Iranian EFL Learners. English Language Teaching, 8(4), p117. https://doi.org/10.5539/elt.v8n4p117

Ko, S. S., \& Rossen, S. (2010). Teaching online: A practical guide (3rd ed). Routledge.

Kumar, N., \& Sharma, S. (2017). Survey Analysis on the usage and Impact of Whatsapp Messenger. Global Journal of Enterprise Information System, 8(3), 52. https://doi.org/10.18311/gjeis/2016/15741

Adhan Kholis

LET: Linguistics, Literature and Language Teaching Journal Vol. 10 No. 22020 
Larsen-Freeman, D., \& Anderson, M. (2011). Techniques and principles in language teaching (3rd ed). Oxford University Press.

Linda, L., \& Ri'aeni, I. (2018). Whatsapp Messenger as a Mobile Media to Learn Writing for EFL Students. JIKE : Jurnal Ilmu Komunikasi Efek, 1(2), 156165. https://doi.org/10.32534/jike.v1i2.156

Lotfi, A. R., \& Pozveh, S. M. H. H. (2019). The Effect of Synchronous and Asynchronous Language Learning: A Study of Iranian EFL Intermediate Students' Vocabulary Learning. Theory and Practice in Language Studies, 9(12), 1585. https://doi.org/10.17507/tpls.0912.16

Manan, N. A. (2017). Whatsapp Mobile Tool In Second Language Learning. Indonesian EFL Journal, 3(1), 87. https://doi.org/10.25134/ieflj.v3i1.657

Mardiana, H. (2020). Lecturers' Attitudes towards Online Teaching in the Learning Process. Register Journal, 13(1), 77-98. https://doi.org/10.18326/rgt.v13i1.77-98

Ma'ruf, Z., Fadilah, N., \& Basofi, P. (2019). English Students' Perceptions of Using WhatsApp in Paragraph Writing Class. International Journal Of Scientific \& Technology Research, 8(10), 6 .

Memić-Fišić, I., \& Bijedić, N. (2017). Teaching materials for ESL distance learning. ExELL, 5(1), 40-54. https://doi.org/10.2478/exell-2018-0003

Mofareh, A. (2019). The Use of Technology in English Language Teaching. Frontiers in Education Technology, 2(3), p168. https://doi.org/10.22158/fet.v2n3p168

Mufanti, R., \& Susilo, A. (2016). Establishing a WhatsApp Conversation: One of Innovations in English Language Teaching. Creativity and Innovation in Language Materials Development and Language Teaching Methodology in Asia and Beyond, 790-796.

Murphy, E., Rodríguez-Manzanares, M. A., \& Barbour, M. (2011). Asynchronous and synchronous online teaching: Perspectives of Canadian high school distance education teachers: Asynchronous and synchronous. British Journal of Educational Technology, 42(4), 583-591. https://doi.org/10.1111/j.1467-8535.2010.01112.x

Nurazizah, H., Friatin, L. Y., \& Sugiarto, B. R. (2019). Whatsapp Voice Note in Speaking Class. Journal of English Education and Teaching, 3(3), 343360. https://doi.org/10.33369/jeet.3.3.343-360

Perveen, A. (2016). Synchronous and Asynchronous E-Language Learning: A Case Study of Virtual University of Pakistan. Open Praxis, 8(1), 21-39. https://doi.org/10.5944/openpraxis.8.1.212

Ra, S., Shrestha, U., Khatiwada, S., Yoon, S. W., \& Kwon, K. (2019). The rise of technology and impact on skills. International Journal of Training Research, 17(sup1), 26-40. https://doi.org/10.1080/14480220.2019.1629727

Robles, H., Guerrero, J., LLinas, H., \& Montero, P. (2019). Online TeacherStudents Interactions Using WhatsApp in a Law Course. Journal of

Adhan Kholis

LET: Linguistics, Literature and Language Teaching Journal Vol. 10 No. 22020 
Information Technology Education: Research, 18, 231-252. https://doi.org/10.28945/4321

Roux, R., Trejo Guzmán, N. P., \& González, E. F. (2014). Distance Education for EFL Teachers: Perceptions of Learner Support. GiST Education and Learning Research Journal, 9 JUL-DEC, 157-178. https://doi.org/10.26817/16925777.149

Saldaña, J. (2011). Fundamentals of qualitative research. Oxford University Press.

Shahabadi, M. M., \& Uplane, M. (2015). Synchronous and Asynchronous elearning Styles and Academic Performance of e-learners. Procedia - Social and Behavioral Sciences, 176, 129-138. https://doi.org/10.1016/j.sbspro.2015.01.453

Shahid, S. (2018). Content Analysis of Whatsapp Conversations: An Analytical Study to Evaluate the Effectiveness of Whatsapp Application in Karachi. International Journal of Media, Journalism and Mass Communications, 4(1), 14-26. https://doi.org/10.20431/2454-9479.0401002

Singh, A. (2018). Facebook, WhatsApp, and Twitter: Journey towards Education. SOSHUM: Jurnal Sosial Dan Humaniora, 8(2), 139-149. https://doi.org/10.31940/soshum.v8i2.987

Susanti, A., \& Tarmuji, A. (2016). Techniques of Optimizing Whatsapp as an Instructional Tool for Teaching EFL Writing in Indonesian Senior High Schools. International Journal on Studies in English Language and Literature, 4(10). https://doi.org/10.20431/2347-3134.0410005

Sutton, B. (2013). The Effects of Technology in Society and Education. The College at Brockport: State University of New York.

YeşiLel, D. B. A. (2016). Technology-enhanced Language Learning for Digital Natives. Participatory Educational Research, 97-111. 